\title{
Orientation and Editorial Group of China Cotton Journal
}

\author{
Huaming Zhang ${ }^{1} \&$ Dawei Liao ${ }^{1}$ \\ ${ }^{1}$ College of Humanities, Donghua University, Songjiang, Shanghai, China \\ Correspondence: Dawei Liao, College of Humanities, Donghua University, Songjiang, Shanghai, 201620, China. \\ E-mail: liaodawei1961@163.com
}

Received: June 29, $2020 \quad$ Accepted: July 5, $2020 \quad$ Online Published: August 31, 2020

doi:10.5539/ass.v16n9p29 URL: https://doi.org/10.5539/ass.v16n9p29

Foundation item: Innovation project for Ph.D. candidate of Donghua University "The arrangement and research of modern Chinese textile history materials" stage of achievements.

\begin{abstract}
China Cotton Journal is the first periodical publication in modern China's textile industry. It was founded by Chinese Cotton Mill Owner's Association, which was founded in Shanghai in 1918. It played an important role in the communication of modern China's textile industry in terms of technology, management, etc. After the departure of the editorial group of China Cotton Journal, some editors founded other textile journals, and some joined other textile journals to continue their editorial work. Therefore, the idea and orientation of China Cotton Journal had an important impact on the textile journals in modern China.
\end{abstract}

Keywords: China Cotton Journal, Chinese Cotton Mill Owner's Association, Editorial Group of Textile Journals

China Cotton Journal was founded in Shanghai on September 20, 1919, edited and published by Chinese Cotton Mill Owner's Association. China Cotton Journal is a typographic printing, and it is sextodecimo. It was successively printed by Star Printing Company, Zhonghua Book Company and World Book Company. At the beginning, it was a quarterly journal. Later, due to the periodical's repeated mistakes and insufficient funds, it was changed into a semiannual journal in June 1931 (Volume 9, issue 1), and it was suspended in December 1934. China Cotton Journal has 12 volumes, 1-8 volumes in four issues, 9-12 volumes in two issues, a total of 40 issues. China Cotton Journal is the first magazine founded and published by Chinese Cotton Mill Owner's Association, and also the first periodical publication in the textile industry in modern Chinese history.

\section{Orientation of Running a Journal}

Jian Zhang wrote in the opening speech of China Cotton Journal: "Chinese Cotton Mill Owner's Association was established the year before last, and China Cotton Journal was established this year to conduct industry communication. It is to use the wisdom of the world to do China's business." Other China Cotton Journal opening speech wrote "I often say that newspapers and magazines have made great contributions to the progress of world culture, In Europe and the United States, every small industry has regularly published industry newspapers and magazines, which provide the industry practitioners with a platform for exchange and communication. Newspapers and magazines play a great role in the development of the industry. It's rare for newspapers and magazines in China. China Cotton Journal is the first magazine in cotton industry. China Cotton Journal, on the one hand, will discuss the changing trend of the world and the supply and demand situation of domestic cotton industry. On the other hand, for technical discussion, publish industry data. It is hoped that China Cotton Journal can comprehensively collect industry information and become an authoritative magazine in the industry. However, it is a difficult task and a heavy one. "It can be seen that the main orientation of China Cotton Journal at the beginning of its establishment was to establish newspapers and magazines in the industry, to deliver information for the textile industry, collect industry information, and share textile technology and data.

However, Jian Zhang's foreword and publication can only reflect the orientation of the journal, and cannot fully understand the purpose of China Cotton Journal. The orientation of China Cotton Journal is gradually accurate in its running process, and its purpose is gradually enriched in this process. The report on the second year of Chinese Cotton Mill Owner's Association states: "The promotion of industrial construction and the sharing of industrial knowledge are all based on the propaganda of newspapers and magazines. China Cotton Journal, 
edited by Chinese Cotton Mill Owner's Association, aims to popularize industry knowledge. "The purpose of running the journal here is to advocate industrial construction and share industrial knowledge". This goal is understood in two levels. "Advocate industrial construction" means to advocate industrial ideas in the whole society, which has gone beyond the scope of the textile industry and has a broader scope. This level is mainly aimed at the impact on the public. On the one hand, "sharing industry knowledge" is to carry out technical communication within the industry. On the other hand, it is to let the public understand the textile industry. These two aims are to further improve the influence of journals. This level is more about the impact on the industry. These two points further enrich the purpose of China Cotton Journal.

The editor of China Cotton Journal discussed the positioning of China Cotton Journal in volume 7, issue 3, "China Cotton Journal is the only publication in China's textile industry, and also the main speech position of practitioners in China's textile industry. Therefore, the development of China Cotton Journal depends on the supervision and help of industry practitioners. China's national textile industry plays an important role, but the situation is very difficult. Only when the industry practitioners are united and self-improvement, can the industry develop. Only the careful study of working technology and factory management can make the whole industry develop smoothly. Once there are relevant research results, they should be published in newspapers and shared with industry practitioners. Only in this way can we achieve the purpose of communication within the industry. Therefore, the theories and academic working methods related to textile dyeing, factory management and labor issues, as well as various surveys and statistics are all the contents that China Cotton Journal hopes to publish, and the journalists of China Cotton Journal hope that the industry practitioners will actively contribute to this journal. "This further clarifies that China Cotton Journal is a speech organ for people in the textile industry to exchange textile dyeing theory, academic working methods, factory management and operation methods, and various surveys and statistics. This discussion enables us to better understand the positioning of China Cotton Journal, and also more accurately explain the positioning of China Cotton Journal on a certain level.

Generally speaking, on the basis of building a good communication platform for the textile industry, it is China Cotton Journal's gradually clear positioning and goal of running the journal to make the public understand the industrial thought and understand the textile industry. This requires that China Cotton Journal not only has theoretical articles that can be understood by the general public, but also has discussions on the frontier of professional technology. This orientation and goal is obviously too high for China Cotton Journal, which has a more and more professional tendency in the process of running a journal. From the memory of Guanyi Qian, editor of China Cotton Journal, we know that the publication of China Cotton Journal was drafted by Guanyi Qian and Zemin Zhang, that is to say, from the beginning, the positioning of China Cotton Journal was closely related to the editorial group of China Cotton Journal. Analysis and understanding of the editing group can better understand the positioning and development goals of the journal, and also can more clearly understand the reasons for the increasing specialization of the journal in the process of running the journal.

\section{China Cotton Journal Editorial Group}

China Cotton Journal does not explicitly mention specific editors, but generally indicates that China Cotton Journal is edited and published by Chinese Cotton Miller Owner's Association. Later, China Cotton Journal mentioned that China Cotton Journal is edited by Chinese Cotton Miller Owner's Association, but the specific staff in the editorial department did not specify. But based on Qian Guanyi's recollection of China Cotton Journal and related articles in China Cotton Journal, we can roughly sort out the editing group of China Cotton Journal. As mentioned before, "Zhang Zemin asked for manuscripts from all sides, Zhuhou Ye asked for advertisements from various foreign banks, and I worked as an editor, proofreader and all the rest in-house." That is to say, the editorial department of China Cotton Journal includes Zhang Zemin, Zhuhou Ye and Guanyi Qian. Guanyi Qian also recalled: "the textile expert has been invited to be the editor in chief. I am still busy with the help from the side, but because the editor in chief has changed many times, initially for Fuzhou Lu, after the Botao Li, Yingshu Yan, Yucheng Luo, recently published for Xinqi Wu, therefore it cannot be published. The belief in the outside world gradually declined, and I focused on the academic writing for the content of China Cotton Journal (published every three months, and it has to be postponed every time, so it can't contain the materials with time.) Another kind of Textile News was created to supplement China Cotton Journal."It can be seen that the editorial department of China Cotton Journal also includes Lu Fuzhou, Botao Li, Yingshu Yan, Lu Yucheng and Xinqi Wu. In addition, the first issue of the seventh volume of China Cotton Journal "editorial room" published the reasons for the wrong issue of China Cotton Journal: "this journal is from Yingshu Yan went to work in other organizations. After leaving the editing room, the editing work of the newspaper stopped. The reporter planned to work overtime in advance, thinking that this could make the periodical published earlier, so as to make up for some time, but still failed to achieve the goal. Since then, we will do our best and work hard 
for the development of the journal and the industry. I hope that readers can help us to work together for better development of the industry. (Bingying Luo) "That is to say, Yingshu Yan and Bingying Luo were members of the editorial department. Yan Yingshu left the editorial department of China Cotton Journal in 1927. After investigation, it was found that the word "Bingying" also mesns "Yucheng", and that Bingying Luo and Yucheng Luo were actually the same person. In the proposal of the board meeting of Chinese Cotton Mill Owner's Association on October 15, 1920, "employment of Nagoya high tech textile graduates Mr.Wang Compile China Cotton Journal with a monthly salary of about 50 yuan." One case, may Nagoya textile college graduate Mr.Wang was hired as an editor with a monthly salary of about 50 yuan. Mr.Wang can't be verified, but the salary of the editor of China Cotton Journal can be roughly understood through this proposal.

Therefore, the editing group of China Cotton Journal is basically known, that is,Zemin Zhang, Zhuhou Ye, Guanyi Qian,Fuzhou Lu, Botao Li, Yingshu Yan, Yucheng Lu, Xinqi Wu, etc. According to the verification and comparison of literature, the basic resume of editing group can be basically restored.

Zemin Zhang is Yi Zhang. Yi Zhang (1885-1946) was born in Zhenjiang, Jiangsu Province. In his youth, he lived in Anqing's uncle's home and studied. In 1901, he was a scholar in the middle of the Qing Dynasty, and then moved to Shanghai for further study. In 1909, he graduated from Fudan University. After graduation, he taught in Hankou higher business school, worked as a compiler in the Commercial Press, and translated geometry. He joined Nanshe in 1911. In 1912, in order to help Fudan to go rebuild school, wrote to Sun Yat-sen jointly. He was appointed Director General of Chinese Cotton Mill Owner's Association and presided over the daily work.

Zhuhou Ye means Yuanding Ye (y.t.yeh), (1891 -?) born in Zhenhai, Zhejiang Province, Bachelor of University of Nanking and master of Georgia University. He used to be a cotton planting officer of Chinese Cotton Mill Owner's Association, and was funded by the Chinese Cotton Mill Owner's Association to study the cotton industry in the United States. After returning to China, he served as professor of agricultural science and director of cotton extension in agricultural science of National Southeast University. Executive director of China Cotton Industry Economic Research Association, director and technical director of crop inspection group of Shanghai Commodity Inspection Bureau of the Ministry of industry, deputy director of the Central Cotton adulterated and banned Institute, director and consultant of the mining and Transportation Department of the gauze Management Committee, and technical member of the cotton industry control committee. He is the author of cotton plant diseases and insect pests, agronomic chemistry, cotton plant species test, etc.

Guanyi Qian (1897-1985), formerly known as Chengfu, from Shaoxing, Zhejiang Province. At the age of 17, he joined the editorial department of Zhonghua Book Company as an intern, followed by Zemin Zhang to work in the Chinese cotton Miller's Association. Editor of China Cotton Journal and Textile News. In 1930, China Textile society was founded. He left the Chinese Cotton Mill Owner's Association and founded textile weekly in his own name in 1931. In 1946, he was appointed by Deputy Secretary General of all-China Federation of cotton textile industry associations. After 1953, he worked in the North Jiangsu cotton textile industry association.

Fuzhou Lu(? -1931), born in Pinghu, Zhejiang Province, he graduated from Tokyo University of Technology, he was the editor of China Cotton Journal after returning to China in 1920. He has successively worked in Shanghai Hengfeng textile new Bureau, Wusong Greater China Textile Company, Xiaoshan Tonghui public yarn factory and Nantong Dasheng No.1 Factory.

Botao Li, graduated from Suzhou Industrial School.

Yingshu Yan, from Fenghua, Zhejiang Province, graduated from Tokyo Institute of Technology. He worked in Shanghai new society and the editorial department of China Cotton Journal. In 1927, he resigned from the editorial department of China Cotton Journal. He reviewed many books, such as practical dyeing, history of China's industry, forestry economics, Chunhui tang theory, middle-class women's home economics textbook, rural education and facilities in the United States and horticultural calendar.

Yucheng Luo, who is a graduate of textile department of Tokyo University of Technology, is Bingying Luo. After returning to China, he served as a technician of Hengfeng mill and editor of China Cotton Journal.

Xinqi Wu (1898-1970), other name is Wenwei. Born in zhouquan Town, Chongde County, Zhejiang Province in 1898. He studied in Japan in 1917, graduated from the textile department of Tokyo University of Technology in 1922, and practiced in the Japanese textile factory for one year. After returning to China in 1923, he served as the technical director of Zhejiang industry department. Since then, he has taught in Suzhou industrial special school, Zhejiang industrial special school, Zhejiang University of technology, Shanghai middle school, Jinan University, Shanghai law school, China public school, etc. In 1934, he became secretary and editorial director of Chinese Cotton Mill Owner's Association. When the cotton industry control committee of the National Economic 
Commission was established, it applied to edit the "cotton monthly". He Advocate academic research of textile industry. At the beginning of Anti-Japanese War, he was appointed as the manager of Tianjin Branch of China Cotton Company. After 1942, he transferred to the post of chief of investigation section of Chengfu Company and chairman of Yushan Textile Company to study the postwar revival plan of China's cotton textile industry. In 1946, he was the factory director of Shanghai No.1 Cotton textile factory of China Textile Company and the consultant of Chengfu Company. In 1949, he acted on behalf of China Textile Corporation in Japan for material exchange. After the founding of the People's Republic of China, he has successively served as the director of Shanghai Guomian No.1 and No.6 factories, the chief of compilation section of East China Textile Administration Bureau, the editor in chief of monthly journal of textile construction, and the engineer of Guomian No.13 factory. He joined the China Democratic League in 1956.

In the editorial group, Guanyi Qian followed Zemin Zhang to work in the Chinese Cotton Mill Owner's Association at the beginning of the founding of the association. As a staff member of the Chinese Cotton Mill Owner's Association, Guanyi Qian was mainly responsible for editing, proofreading and all other work. In 1931, Guanyi Qian left the Chinese Cotton Mill Owner's Association, and the Chinese Cotton Journal was changed into a semiannual in that year. Guanyi Qian has been in charge of editing and publishing China Cotton Journal for a long time since its inception, and has undertaken most of the basic work in the process of editing and publishing China Cotton Journal. Zemin Zhang, as the initiator of the Chinese Cotton Mill Owner's Association federation, had been the director general of the Chinese Cotton Mill Owner's Association before the fall of Shanghai, and was responsible for soliciting manuscripts from all aspects in journal editing. In addition to running a magazine, there are many daily affairs of Chinese Cotton Mill Owner's Association. As the director general, his energy cannot be fully focused on running a magazine, but can only be considered. Zhuhou Ye is a cotton industry officer of Chinese Cotton Mill Owner's Association. He is mainly responsible for the cotton industry investigation. He initially solicited advertisements from foreign banks in the editorial department of China Cotton Journal, and went to the United States to investigate the cotton industry in 1920. He was in charge of journals for a short time. Therefore, the operation of the editorial department of China Cotton Journal is relatively clear. Guanyi Qian is responsible for most of the work of journal editors, and Zhang Zemin is responsible for some of the work of manuscript solicitation. At the beginning of China Cotton Journal's publication, it was determined to hire technical experts as editor in chief of China Cotton Journal. Therefore, the editor in chief has been technical experts since Fuzhou Lu. Experts are employed as editor in chief mainly for the consideration of manuscript source. On the one hand, technical experts can write relevant technical contributions by themselves, on the other hand, it is more convenient for technical experts to ask for contributions from each other. That is to say, the main work of the editor is to provide content services for China Cotton Journal.

The editor in chief of China Cotton Journal has a high degree and basic background of studying abroad. Most of the editors in chief of China Cotton Journal graduated from Tokyo University of Technology. Before being editor in chief of China Cotton Journal, many of them had relevant working experience in textile enterprises. Therefore, there are many textile experts in the editor's classmates and colleagues, which can better provide rich and good sources for journals. In a word, China Cotton Journal has cultivated talents for modern Chinese textile journals and set up the standards for editing textile journals.

\section{References}

China Cotton Journal. (1919-1934).

Front line daily. (1946).

Jin, J. L. (2006). A follow-up report on Fudan's discovery of China's first university diploma, Archives and construction.

Minutes of the Chinese Cotton Mill Owner's Association(1927-1928), Shanghai Municipal Archives, File No: S30-1-35.

Monthly Journal of Tokyo University of Technology Student union in China. (1932).

Ren Zhong Monthly Magazine. (1932).

Social Welfare (Tientsin). (1920).

Ta-Kung-Pao (L'Impartial) (Shanghai). (1948).

Textile News. (1927-1932).

The Republican Daily News. (1920). 


\section{Copyrights}

Copyright for this article is retained by the author(s), with first publication rights granted to the journal.

This is an open-access article distributed under the terms and conditions of the Creative Commons Attribution license (http://creativecommons.org/licenses/by/4.0/). 